\title{
Disposal of Fluidized Bed Combustion Ash in an Underground Mine to Control Acid Mine Drainage and Subsidence
}

\author{
Quarterly Report \\ June 1 - August 31, 1998
}

Work Performed Under Contract No.: DE-FC21-94MC29244

\author{
For \\ U.S. Department of Energy \\ Office of Fossil Energy \\ Federal Energy Technology Center \\ P.O. Box 880 \\ Morgantown, West Virginia 26507-0880 \\ RECEIVED \\ MAR 021999 \\ OST1
}

By

West Virginia University

Morgantown, West Virginia 


\section{Disclaimer}

This report was prepared as an account of work sponsored by an agency of the United States Government. Neither the United States Government nor any agency thereof, nor any of their employees, makes any warranty, express or implied, or assumes any legal liability or responsibility for the accuracy, completeness, or usefulness of any information, apparatus, product, or process disclosed, or represents that its use would not infringe privately owed rights. Reference herein to any specific commercial product, process, or service by trade name, trademark, manufacturer, or otherwise does not necessarily constitute or imply its endorsement, recommendation, or favoring by the United States Government or any agency thereof. The views and opinions of authors expressed herein do not necessarily state or reflect those of the United States Government or any agency thereof. 


\section{DISCLAIMER}

Portions of this document may be illegible in electronic image products. Images are produced from the best available original document. 


\section{Progress Report}

for the Period of

June 1, 1998 to August 31, 1998

Phase III, Quarter VII

Project - ETD05 "Disposal of Fluidized Bed Combustion Ash in an Underground Mine to
Control Acid Mine Drainage and Subsidence"
DE-FC21-94MC29244-17

\section{EXECUTIVE SUMMARY}

This project will evaluate the technical, economic and environmental feasibility of filling abandoned underground mine voids with alkaline, advanced coal combustion wastes (Fluidized Bed Combustion -FBC ash). Success will be measured in terms of technical feasibility of the approach (i.e. \% void filling), cost, environmental benefits (acid mine drainage and subsidence control) and environmental impacts (noxious ion release).

Phase I of the project was completed in September 1995 and was concerned with the development of the grout and a series of predictive models. These models were verified through the Phase II field phase and will be further verified in the large scale field demonstration of Phase III. The verification will allow the results to be packaged in such a way that the technology can be easily adapted to different site conditions. Phase II was successfully completed with 1000 cubic yards of grout being injected into Anker Energy's Fairfax mine. The grout flowed over 600 feet from a single injection borehole. The grout achieved a compressive strength of over $1000 \mathrm{psi}$ (twice the level that is needed to guarantee subsidence control). Phase III is to take 26 months and will be a full scale test at Anker's eleven acre Longridge mine site.

It is expected that the FBC ash will replace what is now an acid mine pool with alkaline solid so that the groundwater will tend to flow around and through the pillars rather than through the previously mined areas. The project has demonstrated that FBC ash can be successfully disposed in underground mines. Additionally, the project is directed towards showing that such disposal can lead to reduction or elimination of environmental problems associated with underground mining such as acid mine drainage and subsidence.

During Phase III the majority of the activity involves completing two full scale demonstration projects. The eleven acre Longridge mine in Preston County will be filled with 53,000 cubic yards of grout during the spring of 1998 and monitored for following year. The second demonstration involves stowing 2000 tons of ash into an abandoned mine to demonstrate the newly redesigned Burnett Ejector. This demonstration is anticipated to take place during the winter of 1997. 
This document will report on progress made during Phase III. The report will be divided into four major sections. The first will the Hydraulic Injection component. This section of the report will report on progress and milestones associated with the grouting activities of the project. The Phase III tasks of Economic Analysis and Regulatory Analysis will be covered under this section. The second component is Pneumatic Injection. This section reports on progress made towards completing the demonstration project. The Water Quality component involves background monitoring of water quality and precipitation at the Phase III (Longridge) mine site. The last component involves evaluating the migration of contaminants through the grouted mine. A computer model has been developed in earlier phases and will model the flow of water in and around the grouted Longridge mine. 


\section{A. Hydraulic Injection}

\subsection{Task Description:}

Task 11 - Hydraulic Injection: The purpose of this task is to grout the eleven acre Longridge mine with a grout consisting of coal combustion byproducts.

Task 12 - Economic Analysis: Burnett Engineering, Inc. shall develop economic analyses to compare the cost associated with disposal of coal ash in landfills with disposal of coal ash in underground mines to control subsidence and acid mine drainage.

Landfill disposal of MEA AFBC Power Plant ash. Burnett Engineering, Inc. shall develop an economic analysis for disposing of MEA AFBC ash in a landfill located near the Fairfax and Longridge mines. Costs to be included in the economic analysis include, but are not limited to, loading of ash at the power plant, transportation to the disposal site, landfill construction, landfill operation, landfill maintenance, and regulatory compliance. In addition, long-term cost impact on property values shall be estimated.

Landfill disposal practices of Northeast utilities. Burnett Engineering, Inc. shall use published data from the Electric Power Research Institute, and data from Monongahela Power Company and Allegheny Power Company to generate a range of cost estimates for disposing power plant ash in landfills. Burnett Engineering, Inc. shall describe the similarities and differences in ash disposal practices and costs for three utilities. Description of the similarities and differences shall include, but is not limited to, regulatory environment, environmental protection features in landfill design (e.g., liners), monitoring requirements, transportation, and ash handling.

Underground coal mine disposal of MEA AFBC Power Plant ash. Burnett Engineering, Inc. shall develop an economic analysis for disposing of MEA AFBC ash in the Longridge coal mine. Costs to be included in the economic analysis include, but are not limited to, loading of ash at the power plant, transportation to the disposal site, production of grout, injection of grout, mine maintenance, and regulatory compliance.

Burnett Engineering, Inc. shall analyze the costs associated with the benefits of underground mine disposal of the MEA AFBC Power Plant ash. These benefits include, but are not limited to, lower quantities of waste to be placed in the landfill, reduction in land subsidence, and improvements in water quality.

Task 13 - Water Quality Model: WVU shall use existing water quality model(s) or modifications of existing water quality model(s) to estimate the impact of ash disposal in underground mines on the concentrations of contaminants in nearby surface and ground water. Data from a geographical information system (GIS) 
shall be coupled with the water quality model results to estimate the impact of disposal of MEA AFBC ash in the Longridge mine on concentrations of contaminants in nearby surface and ground water.

Task 14 - Regulatory Analysis: WVU shall review existing Federal, State of West Virginia, and local regulations and policies which could impact the disposal of ash from advanced coal combustion technologies in underground mines. The contractor shall identify any regulatory barriers to the widespread adoption of this disposal practice in West Virginia.

\subsection{Summary of Accomplishments}

2.1 The proper value for the plastic viscosity of the AFBC ash grout has been established.

2.2 Successful simulations of the partial injection of the AFBC ash grout in an underground mine with a simple layout have been performed with Groutnet.

\subsection{To-Date Accomplishments}

Successfully completed Phase II grout injection. Completed site preparation activities for Phase III Demonstration.

\subsection{Technical Progress Report}

\section{Methodology}

The objective of this stage of the project was to design a grout mix for the initial injection of the Longridge mine. The following evaluation criteria were established for the designed grout:

- $\quad$ use the 18,000 ton of Cement Kiln Dust (CKD) presently at the site.

- $\quad$ possess a reasonable degree of stability.

- $\quad$ be able to flow sufficiently without the addition of a foaming agent.

- be economical to produce on a large $\left(53,000 \mathrm{yd}^{3}\right)$ scale.

Since the volume to be grouted in the Longridge mine is approximately $53,000 \mathrm{yd}^{3}$, the complete use of the Cement Kiln Dust at the site would imply a content of $680 \mathrm{lbs} / \mathrm{yd}^{3}$. This amount of Cement Kiln Dust in the grout should be able to chemically combine with any excess bleed water and eliminate the need for expensive additive agents, such as bentonite.

The ability of the grout to flow was quantitatively measured by performing spread tests. This test is performed by filling a hollow, $3^{\prime \prime} \times 6^{\prime \prime}$ open-ended cylinder with a sample of grout. When the cylinder is quickly lifted off the surface, the grout forms a circular mound, and the thickness and average diameter of the mound is recorded. The yield stress of the grout is calculated 
with the radial spread formula presented by ASTM, STP1331 (Gray, Reddy, Black and Ziemkiewicz, 1997) using the mound's dimensions and the specific weight of the grout. The specific weight of the grout was calculated from the grout mix and the solids density of the grout's ingredients and checked with direct measurements. In order to ensure that the grout would be able to flow through most, if not all, sections of the Longridge mine, a spread of no less than 9 " was allowed for the designed grout. This requirement was taken from the standards for controlled low-strength material (Monson, 1997).

\section{Laboratory Tests}

The following two laboratory tests were conducted to determine the grout mix that satisfied the aforementioned design criteria. The results of these experimental tests are listed below in Table 1. The yield stress values reported in Table 1 were calculated from the spread test, and the specific weights were determined by direct measurement. The reported standard spread widths were

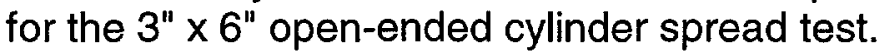

With the smaller water content, the 09/08/1998 test mix had very little bleed water with excellent workability. Unfortunately, the large Cement Kiln Dust content of this mix prevents it from being used for the Longridge mine injection. The 09/11/1998 test mix used slightly less than the maximum Cement Kiln Dust content but had somewhat more bleed water due to its higher water content. The 09/11/1998 test mix had a lower yield stress and corresponding greater spread width and greater workability. While the $09 / 11 / 1998$ test mix is probably acceptable for the Longridge mine injection, the additional stability observed with the lower water content of the 09/08/1998 test mix suggests that the final mix design should possess a water content of approximately $32 \%$. 
Table 1. Experimental Grout Mixes.

\begin{tabular}{|c|r|r|}
\hline $\begin{array}{c}\text { Experimental } \\
\text { Parameter }\end{array}$ & $\begin{array}{r}09 / 08 / 1998 \\
\text { Grout Mix }\end{array}$ & $\begin{array}{c}\text { 09/11/1998 } \\
\text { Grout Mix }\end{array}$ \\
\hline Water Mass Content & $32.4 \%$ & $33.0 \%$ \\
\hline CKD Solids Mass Content & $45.5 \%$ & $36.1 \%$ \\
\hline Class F Ash Solids Mass Content & $54.5 \%$ & $63.9 \%$ \\
\hline Specific Weight & $103 \mathrm{lbs} / \mathrm{ft}^{3}$ & $103 \mathrm{lbs} / \mathrm{ft}^{3}$ \\
\hline Yield Stress & $1.1 \mathrm{lbs} / \mathrm{ft}^{2}$ & $0.60 \mathrm{lbs} / \mathrm{ft}^{2}$ \\
\hline Standard Spread & $9.7 \mathrm{in}$ & $10.9 \mathrm{in}$ \\
\hline CKD Content & $855 \mathrm{lbs} / \mathrm{yd}^{3}$ & $671 \mathrm{lbs} / \mathrm{yd}^{3}$ \\
\hline Class F Coal Ash Content & $1026 \mathrm{lbs} / \mathrm{yd}^{3}$ & $1187 \mathrm{lbs} / \mathrm{yd}^{3}$ \\
\hline Water Content & $108 \mathrm{gal} / \mathrm{yd}^{3}$ & $110 \mathrm{gal} / \mathrm{yd}^{3}$ \\
\hline
\end{tabular}

\section{Design Results}

Given the need to maintain the flow characteristics of the 09/11/1998 test mix with the minimal bleed water observed with the 09/08/1998 test mix, this design modify the 09/11/1998 mix by increasing the Cement Kiln Dust content to the predetermined maximum of $680 \mathrm{lbs} / \mathrm{yd}^{3}$ and reducing the water content to the amount of the 09/08/1998 test mix. This change should reduce the amount of bleed water without significantly changing the yield stress or the specific weight of the grout. The mix design listed below in Table 2. The quantities of the solid ingredients are given in terms of pounds of ingredient per cubic yard of grout; the water content is given in terms of gallons of water per cubic yard of grout.

Table 2. Final Longridge Mix Design.

\begin{tabular}{|c|c|}
\hline Design Parameter & Numerical Value \\
\hline Cement Kiln Dust Content & $680 \mathrm{lbs} / \mathrm{yd}^{3}$ \\
\hline Class F Coal Ash Content & $1210 \mathrm{lbs} / \mathrm{yd}^{3}$ \\
\hline Water Content & $109 \mathrm{gal} / \mathrm{yd}^{3}$ \\
\hline Specific Weight & $104 \mathrm{lbs} / \mathrm{ft}^{3}$ \\
\hline
\end{tabular}

\section{Operational Calculations}

With the final grout design, it is possible to perform the operational calculations. The operational calculations will tell the operators of the mine injection the demand for water, Cement Kiln Dust and Class F Coal Ash at any 
given injection rate and provide a means for determining the total volume grouted from the usage of either Cement Kiln Dust or Class F Coal Ash. With the design mix presented above in Table 2, $1.65 \mathrm{yd}^{3}$ will be grouted for every ton of Class F Coal Ash, and $2.94 \mathrm{yd}^{3}$ will be grouted with every ton of Cement Kiln Dust. The results of the other operational calculations are presented below in Table 3.

Table 3. Results of Operational Calculations for Final Design Mix.

\begin{tabular}{|c|c|c|c|}
\hline $\begin{array}{c}\text { Injection Rate } \\
\left(\mathbf{y d}^{\mathbf{3}} / \mathbf{h r}\right)\end{array}$ & $\begin{array}{c}\text { Water Demand } \\
\text { (gal/min) }\end{array}$ & $\begin{array}{c}\text { CKD Demand } \\
\text { (tons/hr) }\end{array}$ & $\begin{array}{c}\text { Class F Ash } \\
\text { Demand (tons/hr) }\end{array}$ \\
\hline 100 & 181 & 34 & 61 \\
\hline 110 & 200 & 37 & 67 \\
\hline 120 & 218 & 41 & 73 \\
\hline 130 & 236 & 44 & 79 \\
\hline 140 & 254 & 48 & 85 \\
\hline 150 & 272 & 51 & 91 \\
\hline
\end{tabular}

\section{Conclusions}

An economical mix for the grout injection at the Longridge mine has been designed. The presented design should be able to flow through most, if not all, of the sections of the mine. However, the grout injection of some of the smaller, partially collapsed portions of the mine may require the addition of foam to the grout mix. From the experimental data presented above, the yield stress of the designed grout can be no greater than $1.1 \mathrm{lbs} / \mathrm{ft}^{2}$. Given that the overall grade of the Longridge mine is $7 \%$ and that the specific weight of the designed grout is $104 \mathrm{lbs} / \mathrm{ft}^{3}$, the theory presented by Gray, Reddy, Black and Ziemkiewicz (1997) predicts that the designed grout should be able to flow through any passageways in the mine with an effective diameter greater than 8".

\section{References}

Gray, D.D., Reddy, T.P., Black, D.C., and Ziemkiewicz, P.F., "Filling Abandoned Mines with Fluidized Bed Combustion Ash Grout," The Design and Application of Controlled Low-Strength Materials (Flowable Fill), ASTM STP 1331, A.K. Howard and J.L. Hitch, Editors, American Society for Testing and Materials, 1997.

Monson, T., Engineering Properties of Controlled Low-Strength Material Using Fly Ash/AMD Sludge, Unpublished Masters Thesis, West Virginia University, Morgantown, WV, 1997. 


\subsection{Plans for Next Quarter}

5.1 Coordinate Phase III injection with coal company personnel.

5.2 Continue with numeric modeling of Longridge (Phase III) grouting operations.

5.3 Regulatory analysis will be updated and a draft report prepared.

5.4 Economic analysis of both technologies will commence and draft report will be prepared. 


\section{B. Pneumatic Injection}

\subsection{Task Description}

The purpose of this task is to inject coal combustion byproducts into an underground mine via the Burnett Ejector. A complete economic analysis will be completed on the feasibility of this method of injection. Two thousand tons of ash are scheduled to be injected.

\subsection{Summary of Accomplishments \& Significant Events}

The fabrication of the camera and lighting mounts were completed.

\subsection{To Date Accomplishments}

Redesigned and manufactured pneumatic ejector.

\subsection{Technical Progress Report}

Attached.

\subsection{Plans for next Quarter}

5.1 Prepare for the large scale demonstration to prove the effectiveness and economic viability of pneumatic injection. 
Pneumatic Stowing of Fill Material Through Boreholes

For

Control of Acid Mine Water Insitu

\author{
by \\ Mackenzie Burnett \\ Burnett Engineering, Inc. \\ 816 North Traver Trail \\ Glenwood Springs CO 81601-2852
}

1 October 1998 


\section{Table of Contents}

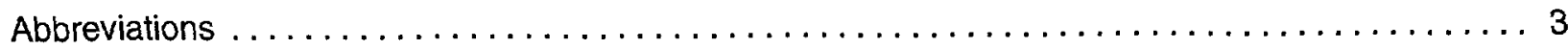

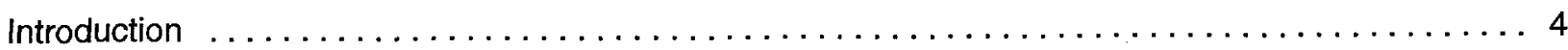

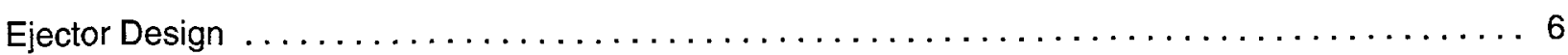

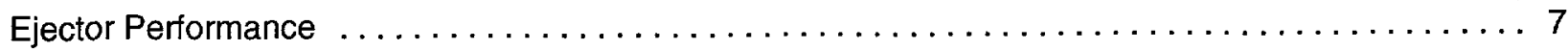

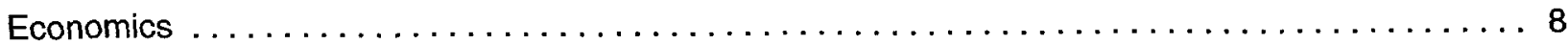

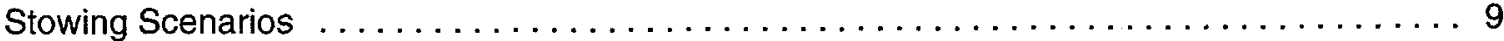

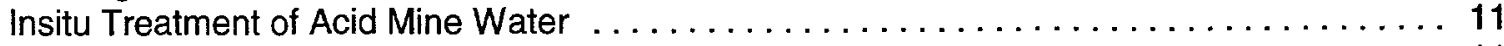

Surface Operations . . . . . . . . . . . . . . . . . . . .

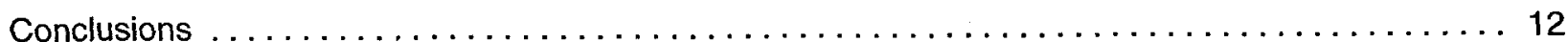

\section{Figures}

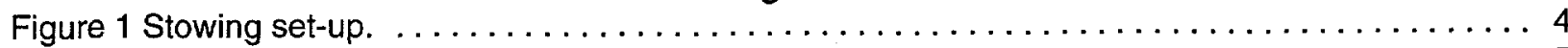

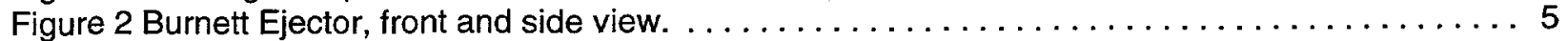

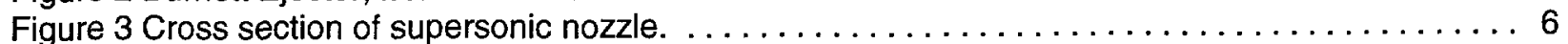

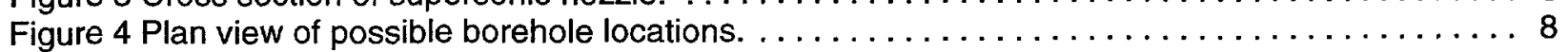

Figure 5 Cross section of stowed void for 30 and $40 \mathrm{ft}$ roof contact. ................. 9

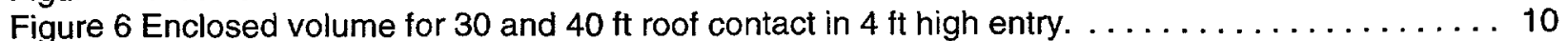

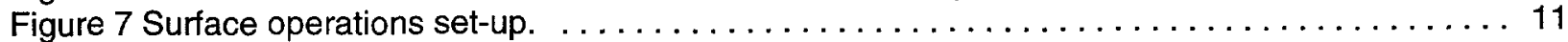

\section{Tables}

Table 1 Estimated performance for ejector for various air flow and stowing material $\ldots \ldots \ldots \ldots 11$

Table 2 Cost factors in underground stowing. . . . . . . . . . . . . . . . . . . 12 
Abbreviations

$\begin{array}{ll}\text { deg } & \text { degrees } \\ \text { diam } & \text { diameter } \\ \mathrm{ft} & \text { feet } \\ \mathrm{ft} / \mathrm{s} & \text { feet per second } \\ \mathrm{ft}^{2} & \text { square feet } \\ \mathrm{ft}^{3} / \mathrm{min} & \text { cubic feet per minute } \\ \mathrm{h} & \text { hour } \\ \text { in } & \text { inch } \\ \mathrm{Ib} / \mathrm{s} & \text { pound per second } \\ \mathrm{Ib} & \text { pound } \\ \mathrm{psig} & \text { pounds force per square inch gage } \\ \mathrm{PVC} & \text { poly vinyl chloride } \\ \text { ton/h } & \text { tons per hour } \\ \mathrm{yd} \mathrm{d}^{3} & \text { cubic yard }\end{array}$




\section{Introduction}

Burnett Engineering, Inc. has demonstrated a unique method of pneumatically stowing large quantities of fly ash or other fill material in underground mines from the surface through boreholes. A patented device known as the Burnett Ejector is the key to the success of the stowing method. The method offers the benefit of being able to build a dam underground to control and treat mine water insitu. Benefits of pneumatic stowing in underground mines are:

- Allows selective placement of fill material to create a dam to isolate acid water in the mine

- By using material containing lime, acid water is treated insitu

- Eliminates the danger of acid mine run off in dry mines

- Provides support to resist subsidence in underground mines

- Requires no water, especially important where water is a scarce resource

- The stowing hardware is inexpensive and virtually free of wear

- Provides a safe disposal site for coal by-products, reducing the surface landfill load

The stowing method consists of a means of pneumatically injecting fill material into mines through boreholes. It differs from conventional methods in that the fill material is accelerated horizontally after it has been dropped down a feed pipe.

Conventional pneumatic stowing, using air-lock feeders, pressurize the material on the surface and blow the material down the borehole at a high velocity. When the material reaches the bottom of the feed pipe, it is either allowed to exit in the vertical downward direction or a mechanical elbow is placed at the bottom of the pipe to turn the material horizontally. In the case of blowing the material straight down without

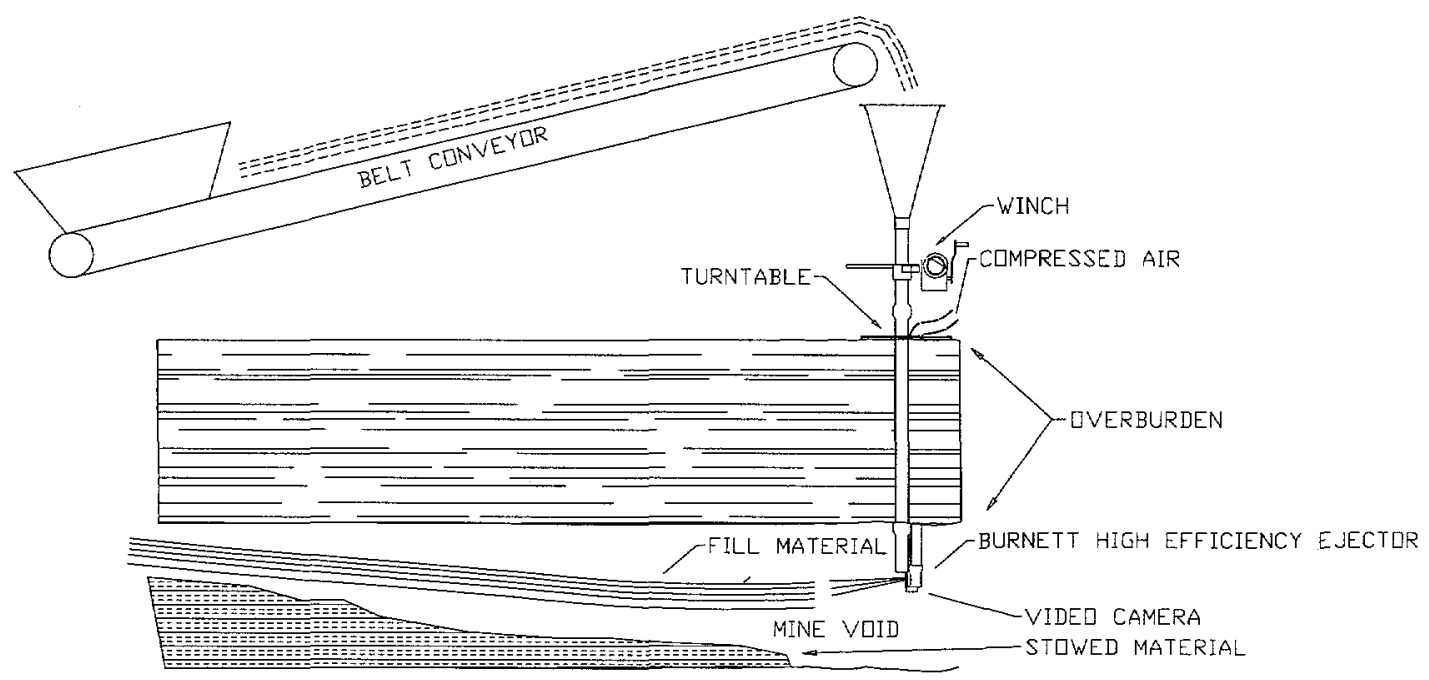

Figure 1 Stowing set-up. 
attempting to turn the material at the bottom, the amount of fill is severely limited since the material chokes off the pipe exit causing the system to plug. In the case of providing an elbow at the bottom to turn the flow, the elbow does turn the flow, but the elbow is subject to severe wear. Once the elbow wears out, which can happen in a very short time, the process reaches the limit as does the system blowing straight down without an elbow.

The system used for this project stows pneumatically, but unlike the conventional methods of turning the fill material is accomplished entirely by a supersonic jet of air. This method has eliminated the wear problem of mechanical elbows and accelerates the fill material to a high horizontal velocity of about $150 \mathrm{ft} / \mathrm{s}$. This method uses two pipes down the borehole, one carrying the fill material and the other delivers $100 \mathrm{psig}$ air to the ejector at the bottom of the borehole. The air is expanded through a set of horizontally directed supersonic nozzles.

The resulting air jet at this pressure ratio results in a velocity of over $1600 \mathrm{ft} / \mathrm{s}$. This jet of air impacts the material falling in the feed pipe at $90 \mathrm{deg}$ and by the process of $\mathrm{mom} e \mathrm{ntu} \mathrm{m}$ exchange, the material is accelerated to at least $150 \mathrm{ft} / \mathrm{s}$ in the horizontal direction. Because the material is turned entirely by air there is no wear on the stowing equipment. The fill material having a high velocity in the horizontal direction, is able to travel considerable distance before it loses momentum and falls to the floor of the mine. As the material falls to the floor it gradually builds up and approaches the roof of the mine. To maximize the e jectors's performance it can be rotated so that it blows in any desired direction. When the
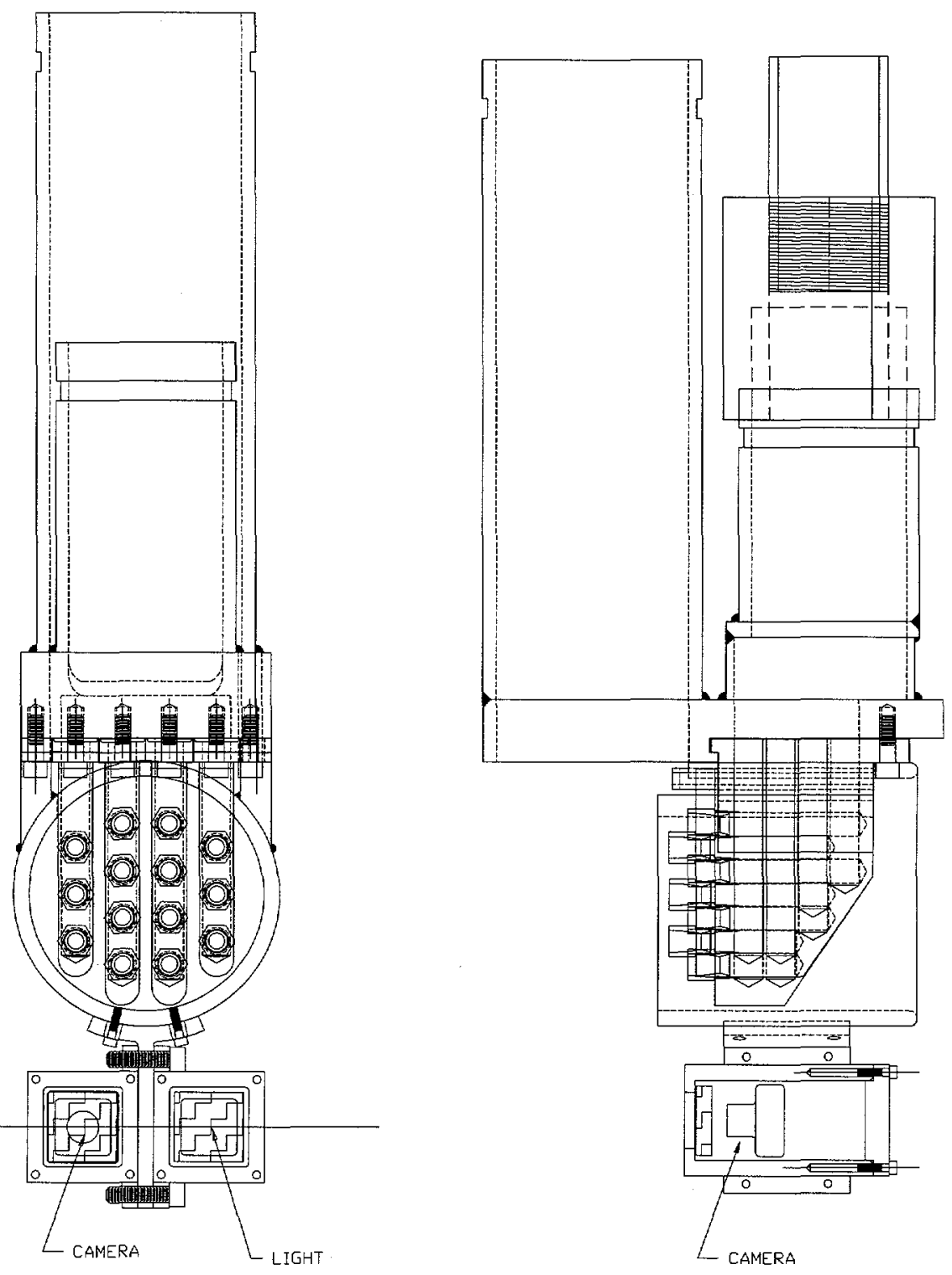

Figure 2 Burnett Ejector, front and side view. 
material that is deposited on the mine floor reaches near the roof, the method of transport of the becomes that of fluid transport, with the lighter particles remaining airborne and the heavier particles saltating along the top of the pile in similar fashion to drifting sand dunes. If there is a high fraction of very small particles, it is possible to blow material for a very long time. The limit of how much material can be blown down a single borehole is reached when the resistance to flow through the small gap between the material and the roof is higher than the total pressure of the air/material stream.

\section{Ejector Design}

A drawing of the Burnett Ejector system in a borehole is shown in Figure 1. The Ejector is designed to fit in an 8-in-diam borehole. The ejector system is supported by a floating turntable mounted on the top of the borehole. The turntable includes a winch and a pipe clamp. This mechanism allows the ejector system to be installed without the use of heavy equipment. Once in place the ejector can be rotated to direct the flow in a full $360 \mathrm{deg}$ circle. As shown, the fill material is fed into a hopper on the surface. The material falls by gravity through the feed pipe and exits the feed pipe just in front of the supersonic nozzles. Figure 2 is a front and side view drawing of the Burnett Ejector. There are 14 supersonic nozzles mounted within a shroud. The jets cover virtually all of the path of the falling material.

The velocity of the airstream produced by the ejector is also of critical importance. Each nozzle is dimensioned to suit the required air flow and pressure to ensure that the airstream attains a supersonic velocity $(1600 \mathrm{ft} / \mathrm{s})$. At this velocity the airstream has sufficient momentum to drive the fill material a great distance from the ejector.

Expansion of the airstream to supersonic velocity is a thermodynamic process based on the concept of a converging/diverging nozzle commonly used in jet aircraft engines. A drawing of a supersonic nozzle is shown in Figure 3.

For very high upstream pressure or very low downstream pressure the discharge velocity from this type of nozzle will be supersonic. To obtain the maximum expansion velocity of a gas a convergentdivergent nozzle must be used. The following relationships for velocities and

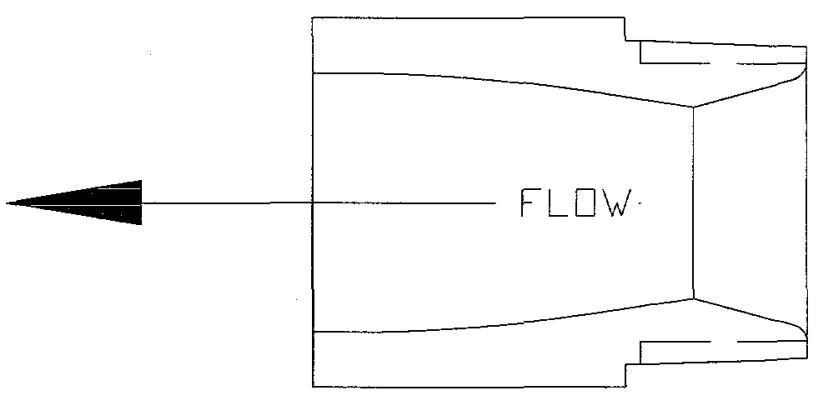

Figure 3 Cross section of supersonic nozzle. areas as a function of pressure can be derived from thermodynamics.

When the slow moving fill material passes by the air jet it is accelerated and the air and solids reach a velocity of approximately $150 \mathrm{ft} / \mathrm{s}$ depending on the solids flow rate. This velocity can be calculated by the following momentum exchange equations.

$$
m_{s} u_{s}+m_{a} u_{a}=m_{s} v_{s}+m_{a} v_{a}
$$

where:

$$
\begin{aligned}
& m_{s}=\text { mass flow rate of solids }(\mathrm{lb} / \mathrm{s}) \\
& m_{a}=\text { mass flow rate of air }(\mathrm{lb} / \mathrm{s}) \\
& u_{s}=\text { initial velocity of solids }(\mathrm{ft} / \mathrm{s}) \\
& u_{a}=\text { initial velocity of air before mixing }(\mathrm{ft} / \mathrm{s}) \\
& v_{s}=\text { final velocity of solids after mixing }(\mathrm{ft} / \mathrm{s}) \\
& v_{a}=\text { final velocity of air after mixing }
\end{aligned}
$$


If we assume $100 \%$ mixing and momentum transfer then:

$$
v_{s}=v_{a}
$$

Solving for $v_{s}$ we get:

$$
\text { (Testing has shown that } \mathrm{v}_{\mathrm{s}}=0.7 \mathrm{v}_{\mathrm{a}} \text { ) }
$$

$$
v_{s}=\frac{m_{a} u_{a}}{m_{s}+m_{a}}
$$

Using this equation it can be determined that to achieve the proposed feed rate of $20 \mathrm{ton} / \mathrm{h}$, an air flow of $1,000 \mathrm{ft}^{3} / \mathrm{min}$ is required. An air flow of $1,000 \mathrm{ft}^{3} / \mathrm{min}$ of air at a velocity of $1,600 \mathrm{ft} / \mathrm{s}$ has sufficient momentum to accelerate the fill material to a velocity of over $100 \mathrm{ft} / \mathrm{s}$. Assuming no air drag on the fill material, this velocity relates to a projection distance of $50 \mathrm{ft}$ from the ejector in a 4-ft mine entry. Because there is air drag, the projection distance is in the range of 30 to $40 \mathrm{ft}$.

\section{Ejector Performance}

The purpose of this work was to reduce the cost of injection of fluidized bed combustion by-products and or other fill materials into underground mine voids. The goal was to improve the performance of the Burnett Ejector by redesigning it to use less air for the same stowing capability.

Two demonstrations of the technology have been conducted. A demonstration in 1994 was conducted using FPC fly ash delivered to the site by pneumatic bulk truck. The stowing operation was easily conducted by one person. The pneumatic truck was able to be unloaded directly into the feed pipe of the ejector. This demonstration proved that fly ash, with its high fraction of very fine material, could be transported up to $100 \mathrm{ft}$ from the injection borehole. The distance that roof contact is achieved is a function of the fine fraction of the material being stowed.

The demonstration conducted in June of 1998 used limestone sand supplied by Greer Industries, Inc. This material could not be handled in pneumatic trucks. It was brought to the site in open tri-axle dump trucks and placed on the ground. A belt conveyor was set up to feed the sand into the hopper. A front end loader was used to keep the hopper on the conveyor full. The conveyor served to control the feed rate to the Ejector system.

The redesigned ejector was installed in a borehole at the Sherman-Helms mine in Preston County on 8 June 98 . The ejector nozzles were redesigned for $1,000 \mathrm{ft}^{3} / \mathrm{min}$ at $100 \mathrm{psig}$. The feed pipe was changed from steel to a high strength PVC and the air hoses used during the last test were replaced with $21 / 2$-in-diam high strength PVC. This made the whole assembly in the borehole less than $150 \mathrm{lb}$. A simple hand winch was used to lower and raise the assembly in the hole. A video camera and light was mounted on the bottom of the ejector to allow proper aiming of the ejector.

Two types of material were tested. Flyash and unwashed limestone sand from Greer Limestone. Material was fed into the system at the rate of 20 ton $/ \mathrm{h}$. The tests showed that the ejector could move sand horizontally up to $35 \mathrm{ft}$ and the fines up to $100 \mathrm{ft}$. No provision had been made to keep the material dry during wet weather. As a result most of the material delivered became wet with the daily rain storms. This wet material tended to cake on the pipe walls which caused plugging of the pipe. This was never a problem with flyash delivered in pneumatic trucks during the previous demonstration.

The results to date indicate that with dry material the ejector will be an efficient method of injecting flyash and other fine materials through boreholes into underground mines. Although the camera worked as 
designed, it was difficult to keep it clean. Future designs will provide for the camera to be lowered through the feed pipe to aim the ejector and then pulled out before material injection is started.

A hopperisused if the material does not lend itself to pneumatic bulk trucks. If fly ash is used as the fill material, then the material can be delivered to the site in pneumatic bulk trucks. In this case the bulk truck can be connected directly to the feed pipe. This method is a very simple operation. It is completely unaffected by weather and no dust or spillage is likely.

\section{Economics}

Testing of the Burnett Ejector on this project and others in the past ${ }^{1}$ has demonstrated that the ejector can move material at least 30 from the borehole with full roof contact. The Burnett Ejector was originally developed for stowing gravel up to $3 / 4$-in-topsize. On this project the Burnett Ejector was improved an designed specifically for finer material such as fly
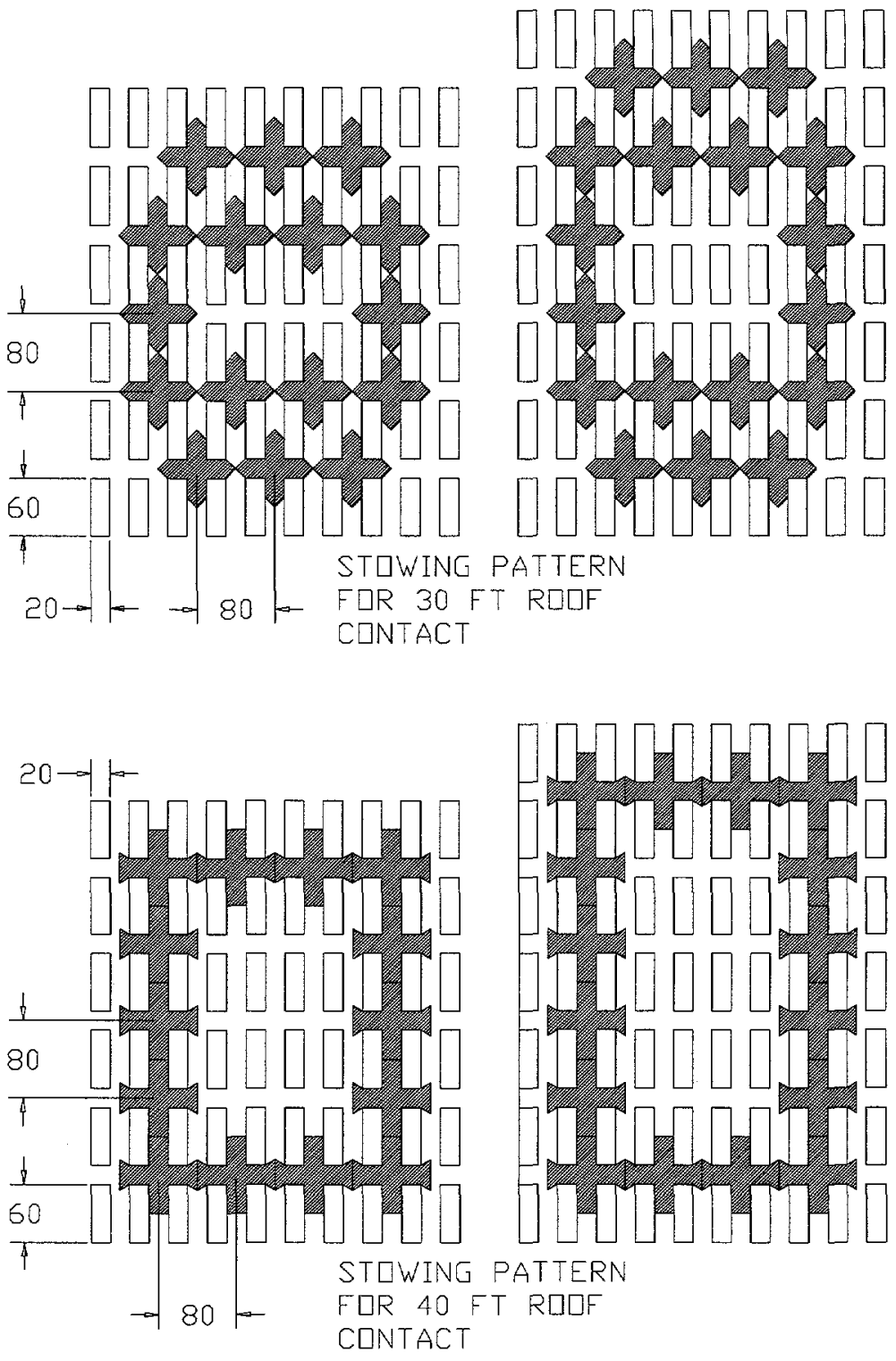

Figure 4 Plan view of possible borehole locations.

ash and sand. Tests have shown that flyash can be moved horizontally over $100 \mathrm{ft}^{2}$ and limestone sand can be moved horizontally 30 to $40 \mathrm{ft}$ in a $4 \mathrm{ft}$ high entry. In any pneumatic stowing operation through a borehole,

${ }^{1}$ U. S, Bureau of Mines Contract J0309012, Development of a High Efficiency Ejector System by Burnett Engineering, October 1991

${ }^{2}$ Roof contact for $100 \mathrm{ft}$ has not been confirmed. 


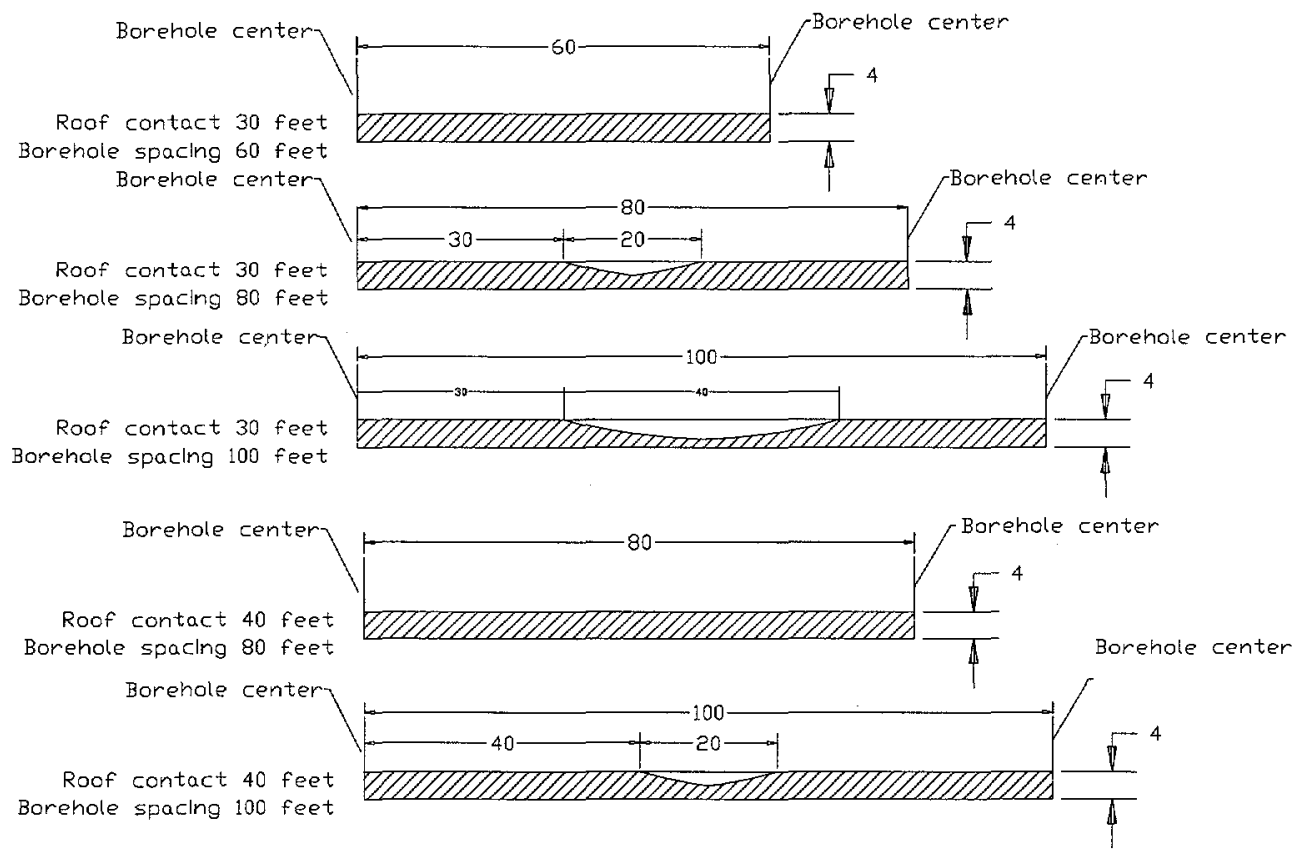

Figure 5 Cross section of stowed void for 30 and $40 \mathrm{ft}$ roof contact.

the limit of the amount and distance that material can be stowed is a function of the percent of material with the larger grain size. When material is blown in essentially still air the larger particle sizes drop out of suspension first. This results in a size separation. When the larger particles drop out and fall to the mine floor, a pile starts to develop which eventually builds to the roof of the mine. When this happens, the process is choked off and material builds up to the point of injection and further stowing is prevented. At this point the ejector can be turned $180 \mathrm{deg}$. If the ejector is stowing material to the roof for $40 \mathrm{ft}$ then from one borehole, an $80 \mathrm{ft}$ stretch of material can be placed from one borehole.

One of the main goals of the design was to have the ability to build an underground dam with stowed material. The dam would enclose a section of the underground mine to trap mine water and allow the water to slowly pass over time through the limestone, thus neutralizing the acid mine run off. Treating the water insitu solves the problem of many small acid laden streams flowing from the mine water. These many small streams are difficult and often impossible to treat once they reach the surface due to expense and/or space.

\section{Stowing Scenarios}

A cross section of the ejector installed in a borehole is shown in figure 1 . The Burnett Ejector is installed on the end of a 3 in-diam material feed pipe and a 2.5-in-diam air supply pipe. The two pipes fit through an 8-in-diam borehole. A funnel type hopper is mounted on the top of the feed pipe. A belt conveyor meters material to the hopper at the design feed rate of approximately 20 ton/h. Compressed air is supplied to the ejector through the 2.5 -in-diam pipe at $100 \mathrm{psig}$ at flow rates ranging from $1,000 \mathrm{f}^{13} / \mathrm{min}$ to $2,000 \mathrm{f}^{13} / \mathrm{min}$ depending on the nozzles selected and the desired performance of the ejector.

If the material to be stowed can be delivered in a pneumatic truck such as fly ash, then the hopper is not needed and the output hose from the pneumatic truck can be connected directly to the feed pipe. 
The process of building an underground dam that will contain the required volume requires that the underground void be mapped and the material to be used in stowing be determined. Ejector performance is a function of air flow and stowing material properties. Finer materials will travel further than the coarser materials. Higher air flow will move material farther. Figure 4 shows a plan view of an idealized mine map and how the boreholes would be placed for an ejector capable of $30 \mathrm{ft}$ roof contact and for $40 \mathrm{ft}$ roof contact. For a $30 \mathrm{ft}$ roof contact scenario, the stowing positions along the horizontal direction (in the figure) are staggered to achieve a dam. In the vertical direction, the borehole positions do not need to be staggered. If the stowing results in a $40 \mathrm{ft}$ roof contact, then a dam can be created without the need to stagger the boreholes. Figure 5 is a cross section view of stowed material in the mine. Figure 6 is calculated volumes for these scenarios showing the number of boreholes and the amount of stowed material for various enclosed (dammed) volumes. The calculations shown by this figure indicate that there is little difference in the amount of stowed material to achieve the same enclosed volume. For example, for $140,000 \mathrm{yd}^{3}$ of enclosed or dammed volume, stowing at $30 \mathrm{ft}$ roof contact would require approximately $12,500 \mathrm{yd}^{3}$ of material using 140 boreholes and stowing at $40 \mathrm{ft}$ roof contact would require approximately $13,700 \mathrm{yd}^{3}$ using 121 boreholes. For $240,000 \mathrm{yd}^{3}$ of enclosed or dammed volume, stowing at $30 \mathrm{ft}$ roof contact would require approximately $20,700 \mathrm{yd}^{3}$ of material and 233 boreholes and stowing at $40 \mathrm{ft}$ roof contact would require a p proximately $19,500 \mathrm{yd}^{3}$ and 180 boreholes. In an actual mine situation the locations of the boreholes would need to be determined based on a study of the mine map, slope of the mine and surface access conditions and the selection of stowing material and ejector air flow. Table 1 shows the estimated performance for the ejector for different materials and air flow rates.
Table 1 Estimated performance for ejector for various air flow and stowing material

\begin{tabular}{|l|l|l|}
\hline $\begin{array}{l}\text { Air flow } \mathrm{ft}^{3} / \mathrm{min} \\
\text { at } 100 \mathrm{psig}\end{array}$ & $\begin{array}{l}\text { Estimated roof } \\
\text { contact distance } \mathrm{ft}\end{array}$ & Material \\
\hline 1,000 & $40+$ & fly ash \\
\hline 1,500 & $50+$ & fly ash \\
\hline 2,000 & $60+$ & fly ash \\
\hline 1,000 & 30 & sand \\
\hline 1,500 & 40 & sand \\
\hline 2,000 & 50 & sand \\
\hline 1,000 & 10 & $3 / 4$ in gravel \\
\hline 1,500 & 20 & $3 / 4$ in gravel \\
\hline 2,000 & 30 & $3 / 4$ in gravel \\
\hline
\end{tabular}

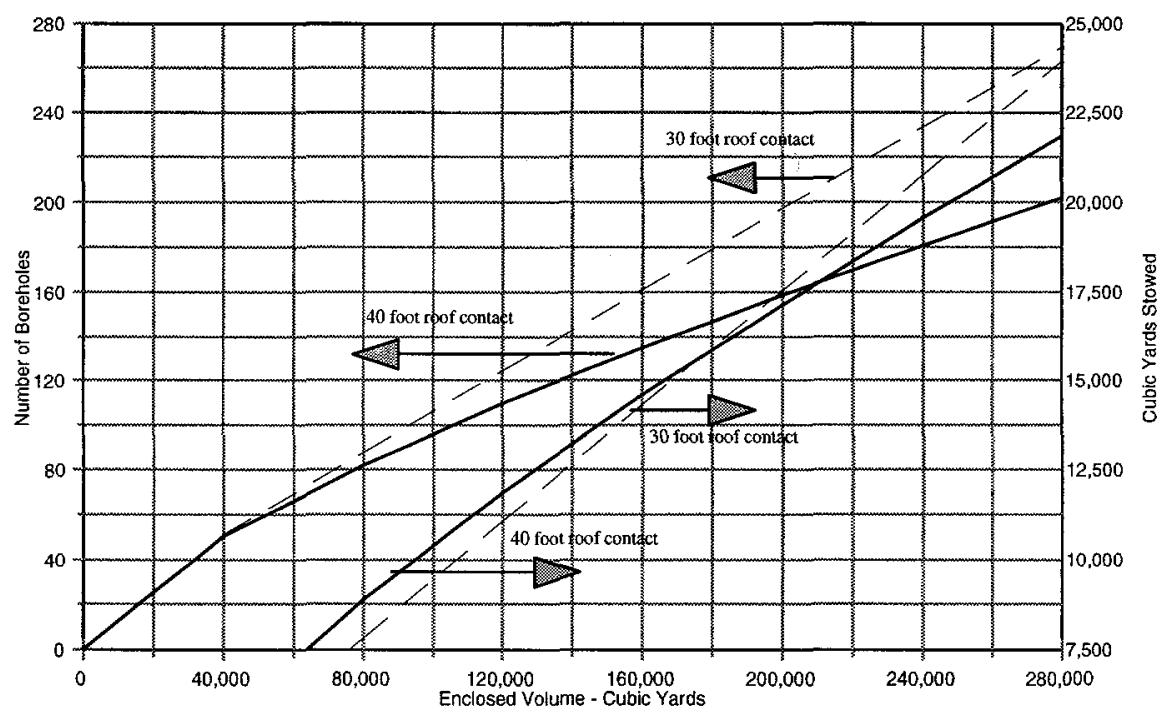

Figure 6 Enclosed volume for 30 and $40 \mathrm{ft}$ roof contact in $4 \mathrm{ft}$ high entry. 
It is anticipated that on a large backfilling project, the facility on the surface could be set up to operate more than one ejector at one time. The material must be kept dry to avoid plugging problems. A material storage shed similar to those used to store highway salt could be used to store and feed multiple belt conveyors that carried the stowing material to each borehole.

\section{Insitu Treatment of Acid Mine Water}

The benefits of insitu treatment of abandoned mine water are many. Insitu treatment eliminates the need for surface treatment which often difficult to accomplish in the limited space. Mine drainage often occurs in many small source points, making treatment impractical. By damming up water with limestone sand in the mine, two beneficial effects will occur. First the acid water will be partially contained by the limestone. Leakage that does occur through the limestone dam will be neutralized by the limestone. Second, as sections of the mine fill with water, the ground water will be diverted and bypass the mine and thus never becoming acid.

\section{Surface Operations}

Figure 7 shows one possibility of setting up surface operations. The goal of the operation is to enclose a certain volume of the mine so that ground water is contained within the enclosure. In figure 4 we saw how stowing at strategic locations results in a volume completely dammed up. Figure 7 is the set-up on the surface. The mine map is shown as dashed lines. A stock pile of material is shown located on the surface at the center of the underground enclosed volume. Four belt conveyors located as shown are able to reach all 16 boreholes. Two short conveyors starting near the stock pile feed material to the two longer conveyors. The two long conveyors, for this assumed set-up would need to be 170 and 126 feet long

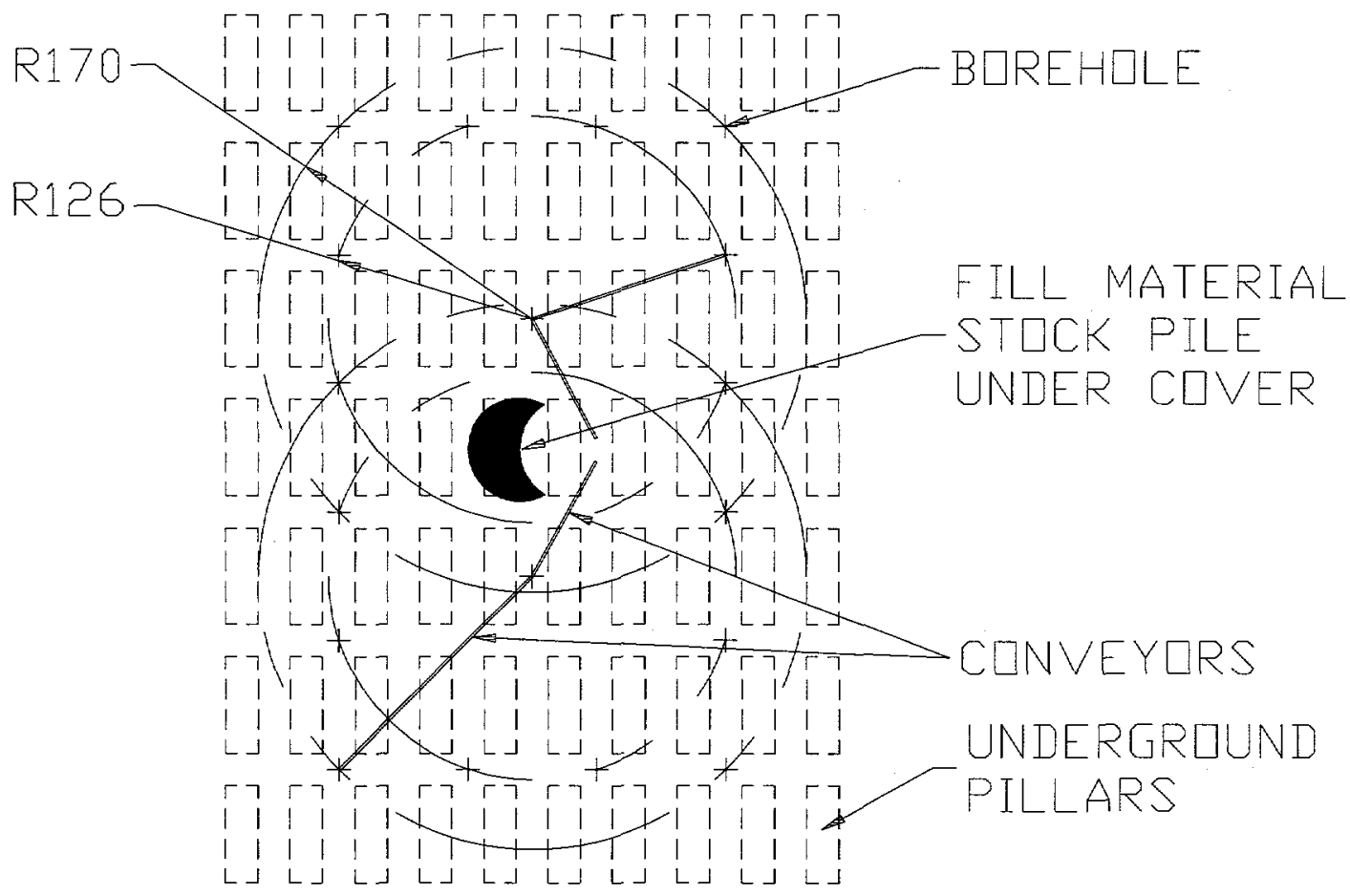

Figure 7 Surface operations set-up. 
respectively. Rotation of these long conveyors allows them to reach each of the boreholes. One loader in the center can then feed both short conveyors. Since the material must be kept dry, the stock pile would be covered. In this scenario two ejectors would be operating at once. Two more ejectors would be installed in the next boreholes so that when the operating ejector filled to refusal, the system could be quickly moved to the next ejector with minimal operating time lost. The first ejector could then be moved to the next open borehole. By leap frogging the ejectors the operating time can be maximized.

Table 2 shows the operating parameters for various ejector performance and for operating for two or one ejectors. Costs shown are purely estimates. It should be noted that the estimated cost of sand is included in the cost per ton. Actual injection costs can be as low as $\$ 3.80$ per ton. We leave it to the contractor to fine tune their costs. There are two groups of data. The first set is for the ejector filling the void to the roof for a distance of 40 feet. The second group is for the ejector filling to the roof for 30 feet. Both sets of figures show estimates for $8,000 \mathrm{yd}^{3}$ enclosed volume and for an excess of $55,000 \mathrm{yd}^{3}$ enclosed volume. Based on the assumptions shown, the costs are lowest when two ejectors are used at once. This is due to cutting the time about in half. The cost is about the same for 40 foot roof contact and 30 foot roof contact on the small enclosed volume, but the cost is substantially less for the 30 foot roof contact on a large enclosed volume. This is due to less material being required. The table and mine plan presented here are idealized. The real conditions will often have irregular mine layouts, however the assumptions are valid for any mine. Proper planning and engineering of a specific project will allow calculation of the costs.

\section{Conclusions}

Pneumatic injection of material through Table 2 Cost factors in underground stowing.

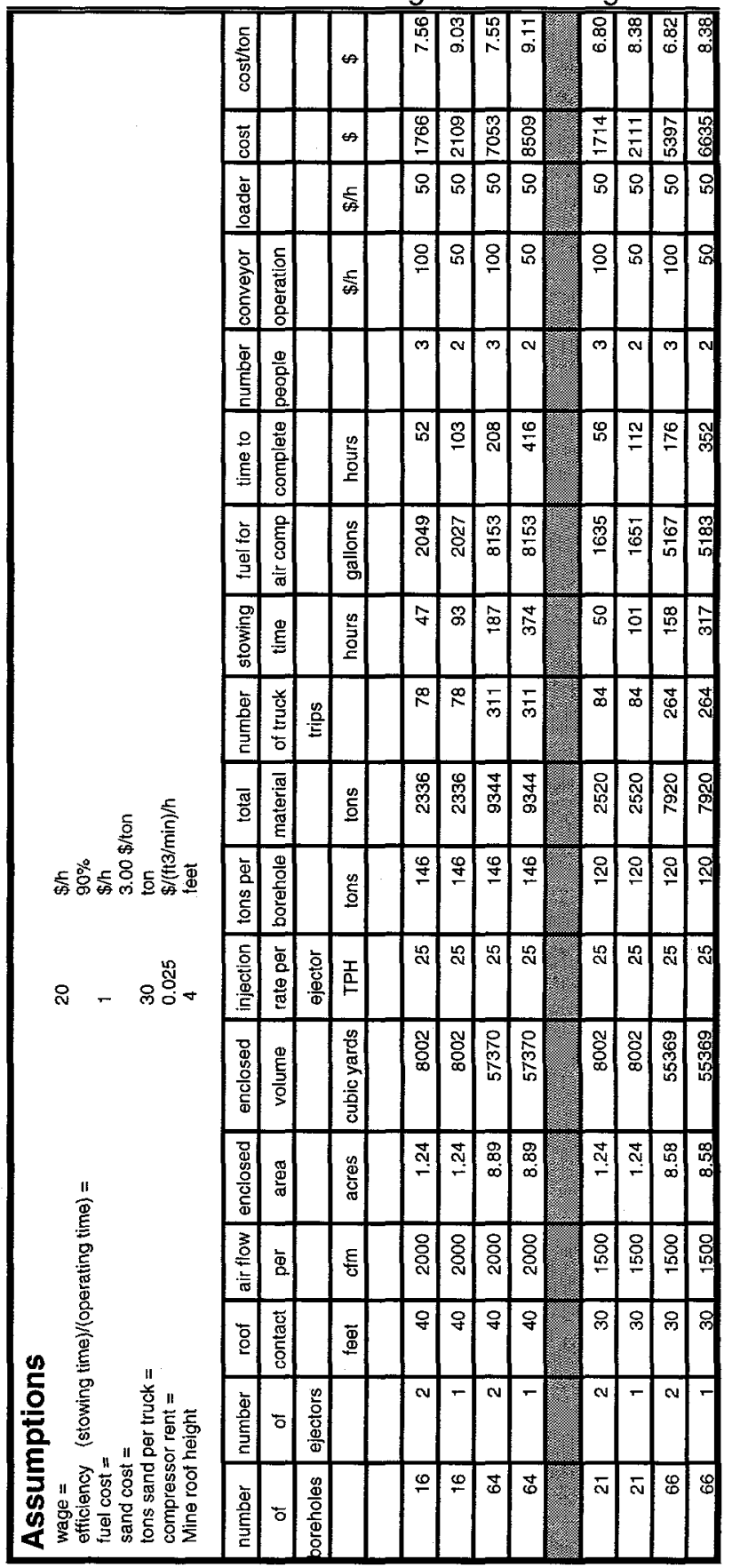
boreholes offers a very controllable method of constructing underground dams to isolate sections of the mine. By isolating controlled volumes underground, acid mine water can be contained and/or treated insitu. This method will be very economical since a relatively small amount of material can be accurately placed to create a dam. Only the material needed to build the dam is required.

The cost of pneumatic injection of material through boreholes is very competitive with other injection methods. 


\section{Contaminant Transport}

\subsection{Task Description}

\section{Task 6.0 Contaminant Transport}

Determine how contaminants will migrate from the grout (if any) and determine how the water that was filling the void will interact with the impermeable plug filling the void after injection.

\subsection{Summary of Quarters Accomplishments and Significant Events}

2.1 Modeling of Contaminant Transport at the Longridge mine was continued to study the influence of grouting.

\subsection{To Date Accomplishments}

3.1 Groundwater flow and contaminant transport simulations were carried out to study the impact of grouting on contaminant transport trends. This study was based on several assumptions on input data since specific data was not available.

3.2 Influence of geometric parameters of the idealized model on computed results was investigated.

3.3 Parametric studies were performed to study the influence of material and geometric parameters on the contaminant transport around a mine cavity.

3.4 Different scenarios of the area around the mine affected by cracks and fissures (i.e. fracture zones) were considered. Several groundwater flow and contaminant transport modeling cases were analyzed based on these scenarios and assumed material properties to study the impact of fracture zones on the contaminant migration trends. These computer results are being analyzed.

\subsection{A draft version of some chapters for the final report were prepared.}

\subsection{Technical Progress Report}

A draft version of the final report is nearing completion. The report will be delivered to U.S. Department of Energy when complete.

\subsection{Plans for the Next Quarter}

5.1 A draft of final report on this task will be prepared. 